\title{
DEVELOPMENT AND VALIDATION OF AN INSTRUMENT MEASURING INFLUENCE OF TIME MANAGEMENT ON WOMEN EMPOWERMENT
}

\author{
LATHA $P^{1} \&$ Dr. RINCY V. MATHEW \\ ${ }^{1}$ Research Scholar, Departmentof Business Administration, Annamalai University, India \\ ${ }^{2}$ Associate Professor, Department. of Business Administration, Annamalai University, India
}

\begin{abstract}
The researcher has gone through the issued scale. Constantly, a sequence of reassessments as well as verification procedures recognized four aspects of Time Management of female micro entrepreneurs of Kudumbashree every estimated with eight, ten, seven and ten units for a total of thirty five units. Comprehensive literature review was carried out to recognize elements within administration of time. A pilot study was carried out to estimate quality of trustworthiness along with correctness of the tool. As an outcome, four elements have been recognized. Confirmatory Factor Analysis has been conducted to decide if the data will suit the four aspect system.
\end{abstract}

KEY WORDS:-Time Management\& Validation of an Instrument

Received: May 25, 2020; Accepted: Jun 17, 2020; Published: Sep 22, 2020; Paper Id.: IJBMRAUG202010

\section{INTRODUCTION}

Housewives of Alappuzha are concernedwith developing their own operations as executively, both in urban as well as rural regions of Alappuzha District through Kudumbashree. This enables them to get over poverty, generate family earnings andalsoraise quality of living. Through micro entrepreneurship, women are able to empower themselves socially, financially and technologically to authorize them to arise in society on their own with credence. It involveshigherself-assurance along with an inner transfiguration of individual'sawareness that makes one defeatoutside problems. The effective management of time enables them to managetheir survival, selfconfidence, self-establishment and direction to attain for themselves. In addition, women micro entrepreneurs are able to improve their personal abilities and make decisions,creatingreputation in the family and society as a successful person.

\section{OBJECTIVES}

- *To develop psychometric instrument for the measurement of time management of female micro entrepreneurs.

- *To analysethe attitude and support of family members towards women micro entrepreneurs to manage their time at home.

- *To know how women micro entrepreneurs utilize their leisure time.

- To compare the marketing strategies before and after proper management of time.

- $\quad$ *To analyse how team members support the micro entrepreneurs to manage time.

- $\quad *$ To study the capacity of women micro entrepreneur to balance their time between home and enterprise 


\section{METHODOLOGY}

Internal stability, dependability of the instrument has been evaluated by Cronbach's alpha. The construct, content and face validities were checked. Confirmatory factor analysis was done to verify the fitness of the details. Literature review has been carried outfor recognizing elements within management of time. As a result, four factors were identified.

\section{ITEMS DEVELOPED}

In order to collect the primary data from women micro entrepreneurs, 35 questions were prepared with a basic knowledge from the questionnaire of Udhay Pareek. In working with others, women micro entrepreneurs have to cooperate with each other; mutual understanding and support must be there. Good training and free time enable them to acquire confidence. Support and care from husband and family give them strength and help them become more empowered. Taking into account these factors, questions were modified.

\section{Methods of Instrument Revision and Validation}

Pilot study was conducted with 60 women micro entrepreneurs of Kudumbashree program in Alappuzha District. It exposed that the altered instrument was trustworthy. The reliability and rationality of the questionnaire have been examined using Cronbach's alpha and construct validity ratio.

KMO and Bartlett's Test Results

\begin{tabular}{|l|l|r|}
\hline Kaiser-Meyer-Olkin Measure of Sampling Adequacy. & .890 \\
\hline Bartlett's Test of Sphericity & Approx. Chi-Square & 5487.180 \\
\cline { 2 - 3 } & df & 595 \\
\hline & Sig. & $\mathbf{0 . 0 0 0}$ \\
\hline
\end{tabular}

The content validity is measured by submitting the measurement tool to subject matter experts and they are asked to provide feedback. From their feedback, it is clear that the tool is valid. Face validity involves the expert looking at the items in the questionnaire and agreed that the tool is subjectively viewed as covering the concept it proposed to measure and it is a valid measurement.

\section{RESULTS AND DISCUSSIONS}

Questions were developed to measure the marketing strategies, saving strategies, how much time spend towards health care, management of time between home and enterprise, support of team members in managing time at enterprise, time spent for societal activities, children and family members.

To analyse the data, a confirmatory factor analysis has been utilized, to test association among variables. As the theoretical examination generated four sub-constructs, confirmatory factor analysis was properly chosen to examine if the data will be suitable for the four elementformation of Time management.

The total variance explained and Eigen values associated with the initial 4 linear components or factors identified in the data set before extraction as well as 4 principal components extracted after extraction and after rotation are shown in Table 


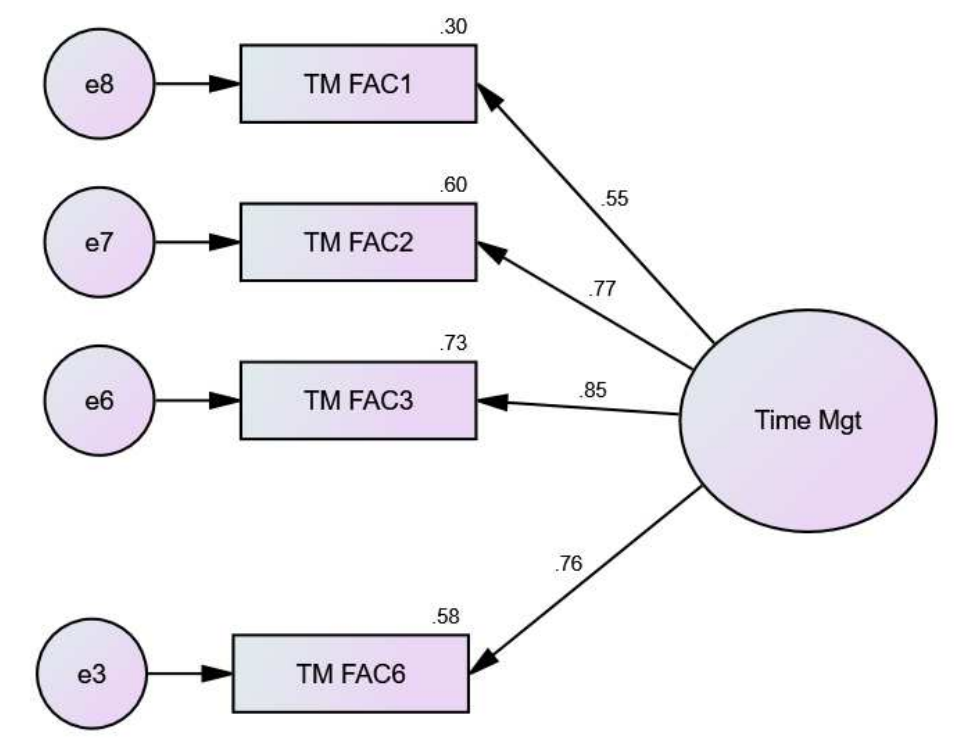

\begin{tabular}{|l|r|r|r|r|}
\hline Dependent Variable: TMEfficiency & \multicolumn{3}{|r|}{ Method: Least Squares } \\
\hline Sample: 300 & & \multicolumn{3}{|c|}{ Included observations: 300} \\
\hline Variable & Coefficient & Std. Error & t-Statistic & \multicolumn{1}{c|}{ Prob. } \\
\hline TMPC1 10.06886 & 0.049504 & -1.391003 & 0.1653 \\
\hline TMPC2 & 0.027364 & 0.003744 & 7.308542 & $\mathbf{0 . 0 0 0 0}$ \\
\hline TMPC3 & 0.031318 & 0.014093 & 2.2223 & $\mathbf{0 . 0 2 7 0}$ \\
\hline TMPC4 & -0.014383 & 0.016751 & -0.858619 & 0.3912 \\
\hline C & 2.702637 & 0.246157 & 10.97933 & $\mathbf{0 . 0 0 0 0}$ \\
\hline R-squared & 0.342118 & Durbin-Watson stat & 1.83432 \\
\hline Adjusted R-squared & 0.333198 & F-statistic & & 38.35225 \\
\hline S.E. of regression & 0.362724 Prob(F-statistic) & $\mathbf{0 . 0 0 0 0}$ \\
\hline
\end{tabular}

The coefficients of TMPC2 and TMPC3 besides the intercept term $\mathrm{C}$ were found to be significant since the null hypothesis that coefficient is zero gets rejected, at 5 percent significance level due to the $\mathrm{p}$ values of their t-statistic being lesser than 0.05 . The model is considered valid since the less than 0.05 probability of $F$ statistics declines the null hypothesis where the fit of the specified model is as good as the intercept only model.

An R-squared of 0.34 and adapted R-squared of 0.33 indicate a reasonably good fit of the model. The near two value of Durbin Watson Statistic specifies the lack of first order serial correlation.

\section{Measurement Mode of Time Management of Women Micro Entrepreneurs}

\begin{tabular}{|l|l|l|}
\hline 1 & I can doseveral roles in a specified time & \multirow{3}{*}{ Self Worthiness } \\
\hline 2 & I perceiveindependent and happy about my work, as I have no dependent care problems. \\
\hline 3 & I should take good care of my husband and children. & \\
\hline 4 & I tried to return from workplace early in the evening. & \\
\hline 5 & I should pay attention to all areas of my enterprise even though I find life exciting. & \\
\hline 6 & I must be flexible with customer's requirement. & \\
\hline 7 & I am confident enough to lead my group. & \\
\hline 8 & I should pay attention to all areas in my life even though I find work exciting. & \\
\hline 9 & I had to exit home very soon in the morning to take part in entrepreneurial task. & \\
\hline
\end{tabular}




\begin{tabular}{|c|c|c|}
\hline 10 & $\begin{array}{l}\text { I do get enough time to take decisions in an important situation both at home and } \\
\text { workplace. }\end{array}$ & \\
\hline 11 & I find my level best to administer my business and dependent care problems concurrently & \multirow{7}{*}{$\begin{array}{l}\text { Balanced Time } \\
\text { Management }\end{array}$} \\
\hline 12 & $\begin{array}{l}\text { My pre-occupation with business does notpermit me to give dependent care requirements } \\
\text { at home, causing to disputes. }\end{array}$ & \\
\hline 13 & Though work/family problems are there, I discover time to take care of my health. & \\
\hline 14 & I find it easy to control the elder care problems. & \\
\hline 15 & My time resources were uniformlyallocatedfor the enterprise as well as home. & \\
\hline 16 & I can concentrate in my business, even though I have dependent care problems & \\
\hline 17 & I find alternatives to take care ofchildcarerequirements. & \\
\hline 18 & I mightdiscover right person for childcare. & \\
\hline 19 & I have become a successful entrepreneur as well as a good homemaker. & \\
\hline 20 & I have plenty of time to spend on family as well as societal commitments. & \\
\hline 21. & $\begin{array}{l}\text { I have to handle both enterprise and family, I could find enough time to participate in } \\
\text { social/community activities. }\end{array}$ & \multirow{8}{*}{ Leisure Orientation } \\
\hline 22. & I find time to attend seminars and yoga. & \\
\hline 23. & I find enough time to compromise my hobbies & \\
\hline 24. & I find time for rest and meditation during free time. & \\
\hline 25. & I feel confident after getting timemanagement classes from SHG. & \\
\hline 26. & I find time to discuss with my husband about how to share housework. & \\
\hline 27. & I am getting adequate rest and sleep in order to cope with work and life. & \\
\hline 28. & I used to attend meditation program at work place after being an entrepreneur & \\
\hline 29 & As the group members cooperate, I am quiet contended in my life. & \multirow{7}{*}{$\begin{array}{l}\text { Shared Management } \\
\text { of Time. }\end{array}$} \\
\hline 30. & $\begin{array}{l}\text { I tried my level best to cooperate with my fellow workers so that I can make alternate } \\
\text { arrangements with other entrepreneurs. }\end{array}$ & \\
\hline 31. & $\begin{array}{l}\text { I can take more relaxed attitude towards housework that the home does not always look } \\
\text { perfect. }\end{array}$ & \\
\hline 32. & It is possible to outsource housework temporarily, when work demand more time. & \\
\hline 33. & I find time to discuss with my teammates about how to share work at enterprise. & \\
\hline 34. & $\begin{array}{l}\text { The long hours of work make me stressed and short tempered. Then my family will give } \\
\text { me support. }\end{array}$ & \\
\hline 35. & My spouse understands and accommodates my preoccupation as an entrepreneur. & \\
\hline
\end{tabular}

Confirmatory factor analysis and reliability examinations for Time Management given statistical assist for a reliable along with valid estimate, proving the four extents of Time Management.

\section{MANAGERIAL IMPLICATIONS}

The scale can be utilized for researchers planning to have their studies in time management, support from family and society, time used for family members and societal activities and utilization of leisure time. This instrument provides a valid tool for further research on time management of women micro entrepreneurs of Kudumbashree. So far, there have not been many measures of time management. It can also be used as an assessment tool and evaluation tool.

\section{CONCLUSIONS}

This study revised Udhay Pareek (2009) instrument to measure time management and provided additional validity evidence. First, acomprehensive literature review has been carried out to assess the theoretical foundation of time management. Specifically, the study identified four dimensions. After discussion with specialists,a pilot study was conducted. After review as well assupervision, a confirmatory analysis has been carried out that proved the four factor structure of time management. The four elements are Self worthiness, Balanced time management, Leisure orientation and Shared management of time. 
Most of the entrepreneurs utilize equal time between home and enterprise. Therefore, they are able to manage the homely duties and entrepreneurial activities in the best way. The scale which is developed measures the effective utilization of time between home and enterprise, time spend for societal activities, time spend for mental, physical and spiritual strength of the entrepreneur.

\section{REFERENCES}

1. Jaya Shukla, GauravBajpai and Tuyishine(2017),The challenges faced by women entrepreneurs in Business expansion,https://www.researchgate.net/publication)

2. KavitaSangolagi and MallikarjunAlagawadi(2016), Constraints in Women ennrepreneurship.

3. Choudhary and Rayalwar(2011),Gender equality in women entrepreneurship .

4. Rana and Masood(2011), Social media marketing-A tool of innovative marketing,International journal of Organization management 3(1),2014) 

